\title{
What Really Happened to Interest Rates?: A Longer-Run Analysis
}

\author{
G. J. SANTONI AND COURTENAY C. STONE
}

I troublesome in recent years. Chart 1 , which shows representative short- and long-term bond yields over the past 27 years, illustrates two perplexing problems with interest rate movements during this period. First, interest rates have risen considerably. In 1954, 3-month Treasury bill rates were close to 1.00 percent and long-term government securities yielded around 2.50 percent; during the second quarter of 1981, the 3-month Treasury bill rate had reached nearly 17.00 percent while the yield on longmterm government securities approached 15.00 percent. Second, associated with this rise in their general levels have been larger and more erratic fluctuations in interest rates as well.

The purpose of this article is to discuss the factors primarily responsible for the rise and increased variability in interest rates in recent years. The analys is is not intended, norcan it be used, to explain every jiggle and jog in interest rates that occurred during this period. Instead, it is meant to uncover those factors that have influenced the longer-term behavior of interest rates over the past 15 years.

\section{A Brief Summary of Interest Rate Movements: 1954-66 and 1967-81}

This article focuses on the changes in the average levels and variability of interest rates that ocm curred between two extended time periods. The first period, 1954 to 1966 , was one in which interest rates were both relatively low and comparatively stable. The second period, 1967 to the present, is one in which interest rates have reached relatively high levels and demonstrated considerably greater variability.

The major changes in interest rates over these two periods are shown in tables 1 and 2 for four different interest rates: the Aaa corporate bond rate, 20-year Treasury security yield, 90-day commercial paper rate and three-month Treasury bill rate. Whether the interest rate analyzed is short- or long-term, or whether a private or government interest rate is chosen, the general picture remains unchanged. On average, interest rates are considerably higher from 384 to 420 basis points higher - in the 1967-81 period than they were from 1954 to 1966 . As the tstatistics in table 1 indicate, these increases are statistically significant, allowing us to reject the hypothesis that the differences in the average levels of interest rates in the two periods merely represent sampling error. ${ }^{1}$

In addition, interest rates have become considerably more volatile in recent years. Their increased variability since 1966 is demonstrated in table 2 using several different measures of variability. Their standard deviations, the commonly used measure of

\footnotetext{
For sample sizes used, a t value in excess of 2.00 is sufficient to reject the (null) hypothesis that the observed difference in the mean values equals zero with 95 percent confidence. This statistical test is predicated on the use of independent random samples. Since our samples are not randomly chosen, we use the $t$ and $F$ tests that appear later in the paper to "provide the basis for a good educated guess - or what we night term the art of inference." (Italics in original) Thomas H. Wonnacott and Ronald J. Wonnacott, Introductory Statistics for Business and Economics, 2nd ed. (John Wiley and Sons, 1977), p. 9. For more on $t$ and $F$ tests, see virterally any statistics text.
} 


\section{chart 1 \\ Representative Short-Term and Long-Term Interest Rates}

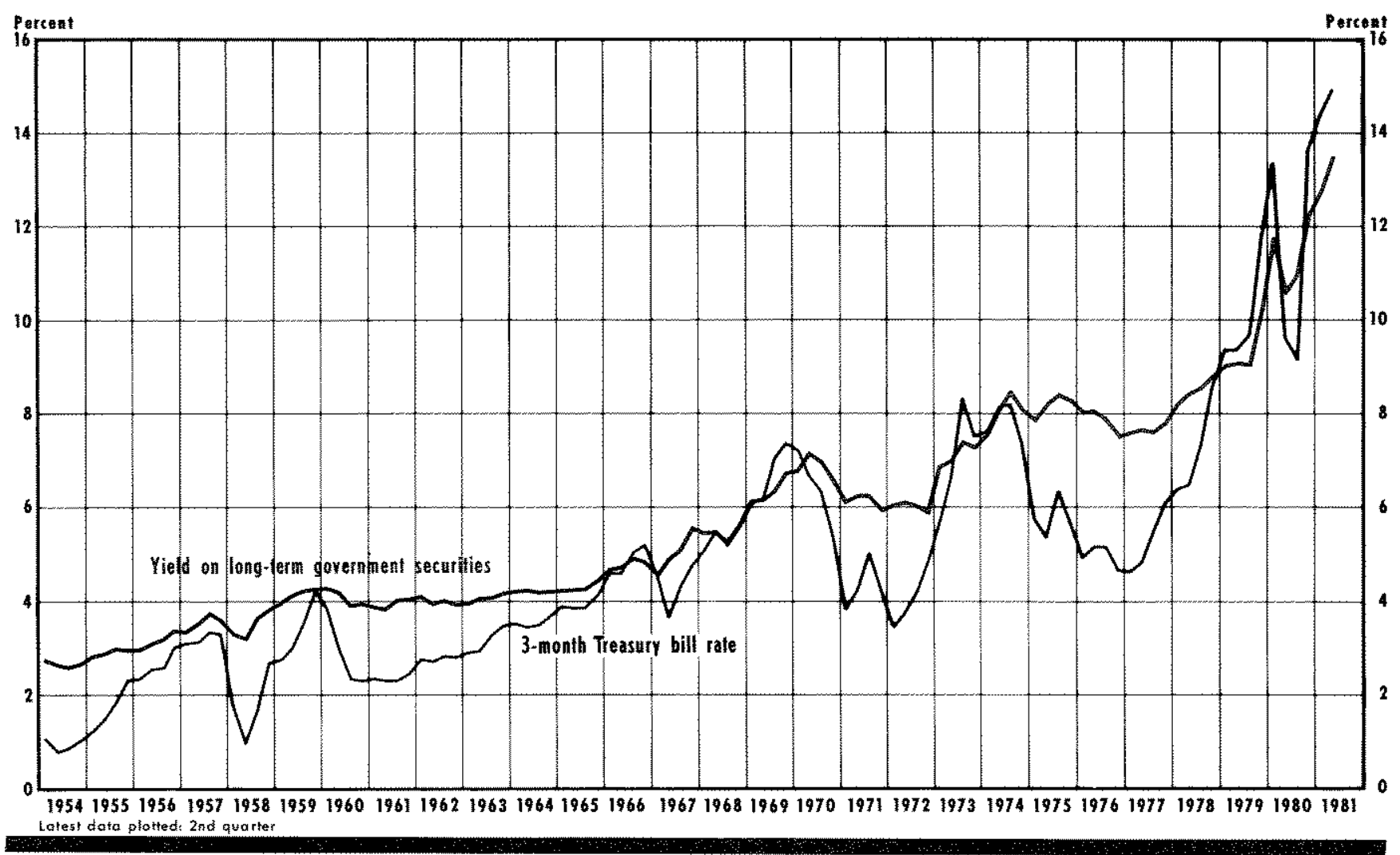

variation around the mean, have more than doubled from the earlier to the later period. In addition, their average quarter-to-quarter absolute changes have tripled, as have their standard errors from regressions of interest rates on a time-trend variable. ${ }^{2}$ These various measures indicate that interest rates have been considerably more variable over the past 15 years than they were from 1954 to 1966.

These increases in both the average levels and variability of interest rates are more than merely statistically significant. The rising volume of public discussion and debate suggests that these changes are economically and politically significant as well. If we are to devise an effective policy to ameliorate the problems created by interest rate movements, it is important that these changes in the longer-term behavior of interest rates be explained.

\footnotetext{
"Average absolute quater-to-quarter changes and standard errors from time-trend regressions were used as measures of variability to see whether changes in the trend growth in interest rates in the later period had aistorted the usefulness of the standard deviation as a measure of variability. Fon further discussion on this issue, see Edward Foster, "The Variability of Inflation,"The Reciew of Economics and Statistics (August 1978), pjp. 346-48.
}

Components of the Nominal Rate of Interest: The Crucial Importance of Expectations

Interest rates observed in financial markets are nominal interest rates. They measure the premium that the borrower must pay in a credit transaction involving the exchange of dollars now in return for a promise to repay dollars at some specified future date. ${ }^{3}$

The parties involved in such contracts are clearly interested in the expected future value of money in terms of goods and services that can be purchased with it when the loan is repaid. Because the value of money varies inversely with movements in the general level of prices - falling during periods of inflation and rising during deflationary periods - the expected inflation rate over the period of the loan is one component of the nominal rate of interest.

${ }^{3}$ For futher discussion of various interest rate concepts, see $\mathrm{C}$. J. Santoni and Courtenay C. Stone, "Navigating Through the Interest Rate Morass; Some Basic Principles," this Reviet (Mareh 1981), pp. 11-18. 
Table 1

Average Levels of Selected Nominal Interest Rates and Average Annual Growth Rates in Money, Velocity, Output and Prices'

\begin{tabular}{|c|c|c|c|c|}
\hline 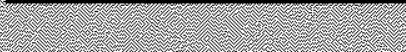 & 195466 & $(9678)$ & Direrchee & t- statistics \\
\hline Aat corporate tond rile & +068 & $8.26 \%$ & 4.21 & 16.8 \\
\hline 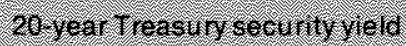 & 3.78 & 762 & 3.54 & 14.38 \\
\hline 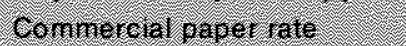 & 3.45 & 761 & 4.16 & 10.46 \\
\hline S. nonth Treasuru bill rate & 286 & 676 & 3.909 & 1024 \\
\hline r & 219 & 643 & 426 & 1.58 \\
\hline MIte & 246 & 8.52 & $4062^{2}$ & 10.0 \\
\hline the & 355 & 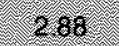 & $=67$ & 126 \\
\hline$y^{2}$ & $=2.80$ & 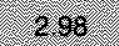 & 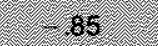 & 105 \\
\hline r & 0.27 & 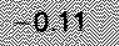 & 26 & 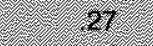 \\
\hline
\end{tabular}

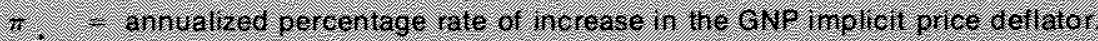

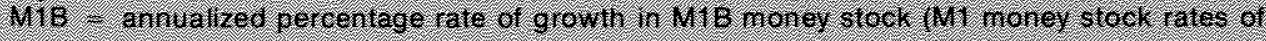
grown tosed pitor to 19.58

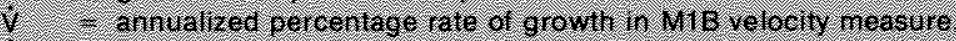

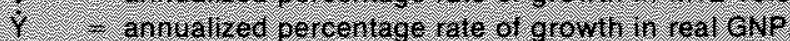

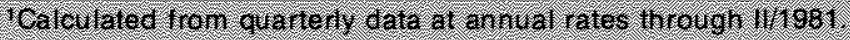

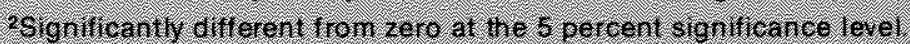

Table 2

Measures of Interest Rate Variability

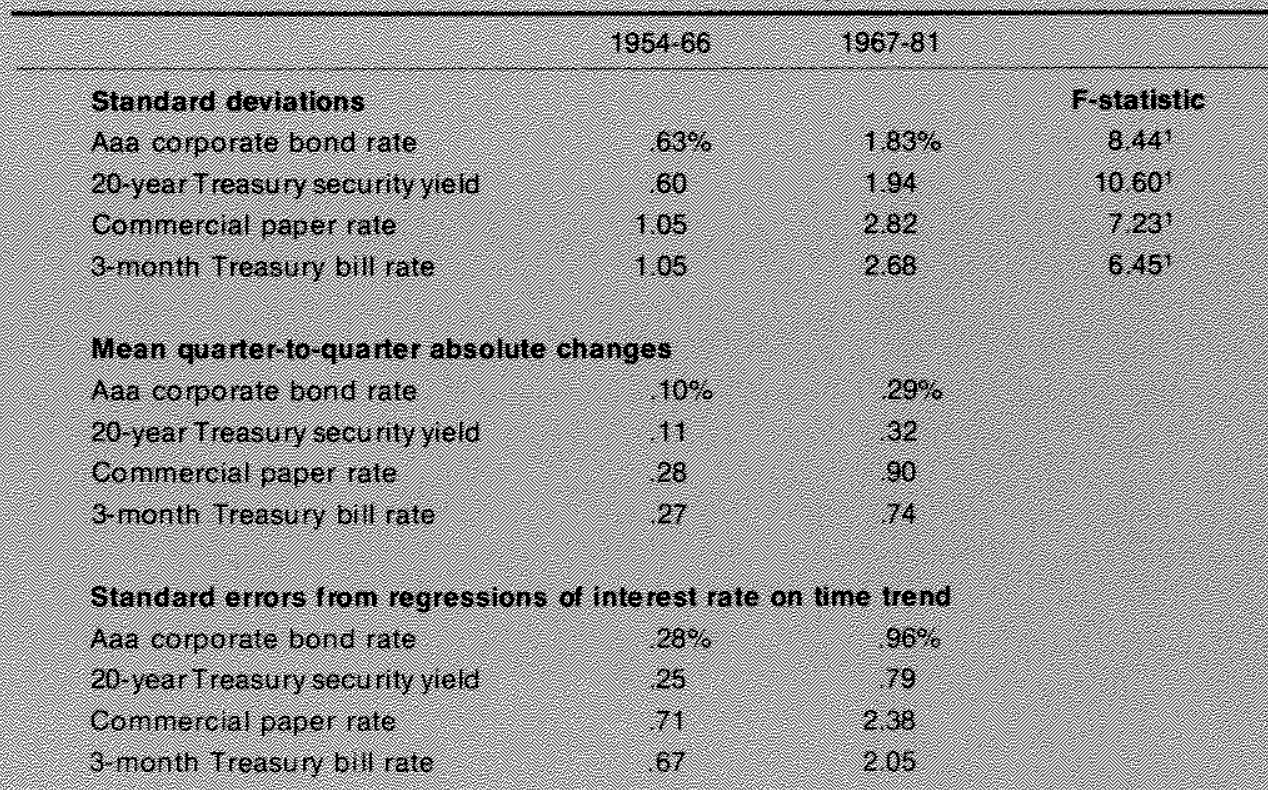

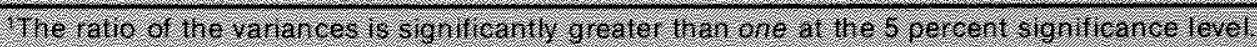


The other component of the nominal rate of interest is the expected or ex ante real rate of interest. The real rate of interest is the relative price paid for obtaining the use of goods now rather than in the future. ${ }^{4}$ Narrowly interpreted, it represents the expected positive cost to the borrower (or retum to the lender) after an adjustment has been made for the expected change in the general price level over the loan period.

More importantly, however, the expected real rate of interest has a pervasive influence throughout the economy because it reflects the premium that individuals place on providing themselves with present consumption goods relative to future consumption. ${ }^{5}$ Movements in the real rate of interest result either from changes in the underlying individual preferences for present consumption goods relative to present capital goods (the sources of future consumption goods) or from changes in society's ability to transform current goods into future goods via changes in the capital stock.

Regardless of what triggers it, any change in the real rate of interest will be reflected in the behavior of the relative prices of current consumption (shortlived) goods in terms of capital (long-lived) goods. A rise in the real rate of interest will show up as a general rise in the prices of current consumption goods relative to capital goods; a decline in the real rate of interest will appear as a decline in these relative prices.

In summary, the nominal interest rate consists of two components that, though not directly observable, influence the actions of borrowers and lenders. The nominal interest rate (i) can be thought of simply as the sum of the expected real rate of interest $(r)$ and the expected future rate of inflation $\left(\pi^{*}\right)$ over the period of the loan, or

$$
\text { (1) } i=r+\pi^{*} \cdot{ }^{6}
$$

The important point to remember is that the nominal rate of interest is always forward looking. It

\footnotetext{
${ }^{4}$ Armen Alchian and William R. Allen, Exchange and Production: Competition, Coordination and Control (Wadsworth, 1977), pp. $424-59$.

${ }^{5}$ Ibid. See also Irving Fisher, The Rate of Interest (The Macmillan Co. 1907), p. 88, and Jack Hirshleifer, Intestment Interest, and Camital (Prentice Hatl, 1970), p. 117 .

"The exact relationship is: $i=r+\pi^{*}+(r)\left(\pi^{*}\right)$. Equation 1 is an approximation that is reasonalyly close to the exact relationship for relatively low rates of inflation and real xates of interest.
}

depends upon the present expectations of borrowers and lenders about future events. ${ }^{7}$

\section{The "Problem" with Guessing Wrong}

Of course, expectations can change - sometimes drastically so. These changes are a source of public concern because lending and borrowing decisions represent bets about the future that involve wealth consequences for individuals. Changes in the nominal rate of interest signal the fact that, in the aggregate, individuals have revised their assessment of the value of present consumption goods in terms of capital goods, their expectations of the future rate of inflation or both. When these changes occur, lenders, borrowers, investors and consumers face the unanticipated wealth consequences of their past decisions. These changes capriciously redistribute wealth among individuals.

Increased variability in the rate of interest implies that such revisions are occurring more often and/or are more drastic in nature. As a result, financial market participants are subject to greater and more frequent unanticipated wealth changes and thus are faced with increased risk.

To assess the factors that have produced increases in both the average level and volatility of nominal rates of interest, we must focus on the behavior of the two components that make up the nominal interest rate: the expected real rate of interest and the expected rate of inflation.

\section{Assessing Changes in the Real Rate of Interest}

To what extent can the observed rise and increased volatility of the nominal rate of interest since 1967 be explained by changes in the real rate of interest? This question cannot be answered directly because the expected real rate of interest is not directly observable.

Since relative price movements always result from changes in the real interest rate, however, it should be possible to detect when these changes

\footnotetext{
T"The rate of interest is al ways based upon expectation, however little this may be justified by realization. Man makes his guess of the future and stakes his action upon it. . . Our present acts must be controlled by the future, not as it actually is, but as it looks to us through the veil of chance." Fisher, The Rate of Interest, p. 213. See also, Irving Fisher, The Theory of Interest (Kelley and Millman, 1954), pp. 13-16, 36-58, 61 and 206-27.
} 
have occurred. ${ }^{8}$ Recall that an increase in the real interest rate will be reflected by increases in the prices of current goods and services relative to present prices of durable goods and capital assets. Similarly, a fall in the real interest rate is reflected as a decrease in prices of current goods and services relative to present prices of durable goods and capital assets.

There are a wide variety of such relative prices that can be observed, several of which were examined for the 1954-66 and 1967-80 periods. Each price ratio expresses the price of a present consumption good relative to the price of a more durable good or capital asset. For example, the consumer price index (CPI) is heavily weighted in terms of present consumption goods; as such, it represents an index of the prices of these goods. ${ }^{9}$ The Standard and Poor's Stock Price Index is a price index of the present prices (actually, net values) of capital goods. Therefore, an increase in the ratio of the CPI to the Standard and Poor's Index can be interpreted as a reflection of an increase in the real rate of interest; a decrease in the ratio denotes a fall in the real interest rate. Similar reasoning applies to the other price ratios examined. ${ }^{10}$ Because it is always possible that special factors may cause individual price ratios to change for reasons other than a change in the real

SOne altemative approach employed has been to estimate the expected inflation rate and subtract this from the nominal interest rate. In essence, this procedure transposes equation 1 to

$$
r_{e}=i-\pi \hat{e}
$$

where $\pi_{\mathrm{e}}^{*}$ denotes an estimate of the expected infiction rate and $r_{e}$ is the derived estimate of the real rate. Unfortunately, these empirical estimates are subject to two major criticisms. First, during certain yeriods, these real interest rate estimates have been negative. This is a nonsensical result. The expected real rate of interest is always positive. See Fried rich A. Hayek, The Pare Theory of Capital (The University of Chicago Press, 1941), pp. 223-24; and Fisher, The Theory of in terest, pp. 186-94. Second, commonly derived estimates of the expected inflation rate are biased if the real rate is changing. leading to emoneous estimates of the real rate if this method is employed. See $W$. W. Brown and $G . J$. Santon: "Unreal Estimates of the Real Rate: of Interest," this Reviete (January 1981), pp. 18-26.

"Bureau of Labor Statistics, Handbook on Methods, Btilletin $1910(1976)$. For a discassion of the various price ind ices currently used, see Willam $\mathrm{H}$. Wallace and William $\mathrm{E}$. Cullison, Measuring Price Changes: A Study of the Price Indexes, 4 th ed. (Federal Reserve Bank of Richmond, 1979).

"oThese ratios are not equal to the ex ante real rate of interest. However, they are functions of the real rate of interest. To see this, let $P_{0}$ equal the price of a present consumption good and let $P_{0}$ equal the present price of a capital good. $P_{c}$ can be represented as follows:

$$
\text { (i) } P_{c}=\sum_{t=0}^{n} \frac{P_{t} \text { at }}{(1+i)^{t}}
$$

rate of interest, the behavior of several such price ratios must be examined.11

\section{Has the Real Rate of Interest Changed?}

The price ratios examined provide evidence that the rise in the average levels of nominal rates of interest was not produced by a rise in the average level of the real rate of interest. ${ }^{12}$ Data on the average level of four price ratios are presented in table 3 ; differences in the average levels of the price ratios between 1954-66 and 1967-80 are presented in column 4 .

Two of the price ratios, the ratio of the CPI to the Standard and Poor's Stock Index and the ratio of the price of lamb to the price of sheep, declined on average, presumably an indication that the real rate of interest declined. Neither of these changes, however, is statistically significant, which means that we cannot reject the hypothesis that the average real rate of interest was actually unchanged between the two periods. Two price ratios, the ratio of the nondurable goods component of the CPI to the durable goods component and the ratio of the price of beef to the price of cattle, rose, on average, ostensibly signaling a rise in the real rate of interest. However, the rise in the average ratio of beef to cattle prices is, again, not statistically significant;

where at represents the quantity of goods and services produced at time $t, P_{t}$ are the prices (net of costs of production) at time $t$, and $i$ is the nominal rate of interest.

Inflation can be introduced into the analysis as follows (using the exact relationship shown in foomote 6 ):

$$
\text { (ii) } \mathrm{P}_{\mathrm{C}}=\sum_{\mathrm{t}=0}^{n} \frac{\mathrm{P}_{\mathrm{O}}\left(1+\pi^{*}\right)^{\mathrm{t}} \mathrm{qt}}{(1+\mathrm{r})^{\mathrm{t}}}=\mathrm{P}_{\mathrm{O}} \sum_{\mathrm{t}=0}^{\mathrm{n}} \frac{\mathrm{qt}}{\left(1+\pi^{*}\right)^{\mathrm{t}}}
$$

where $r$ and $\pi^{*}$ are the $x$ ante reat rate and the expected rate of intation, respectively. This results in

$$
\text { (iii) Index }=P_{0} / P_{e}=\sum_{t=0}^{n} \frac{\frac{1}{\mathrm{n} t}}{(1+x)^{t}}
$$

This index rises whenever rises and falls whenever falls.

"Changes in special circmustances tend to ocur randomy and are as likely to raise as to lower the price ratio.

120 fourse, year-to-year fuctuations in the real rate will occur. For eximple, there is evidence that the real rate of interest rose in 1973-75. See Brown and Santoni, "Unreal Estimates." These fluctuations a re not critical to the present question. We are interested here in whether the average level aromed which these fuctuations occur is different during the more recent period and, if so, to what extent this change explains the difference in the acerage lecel of the nominal interest rate between the two periods. 


\section{Table 3}

\section{Average Levels of Proxies for Changes in the Real Interest Rate!}

\begin{tabular}{|c|c|c|c|c|}
\hline Thato & 195466 & 1967.60 & Dilerenes & 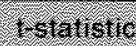 \\
\hline n. & 1,590 & 1.5419 & $=050$ & 30 \\
\hline 72 & ? & $\gamma_{1}, 07$ & $(36$ & 787 \\
\hline 18 & 16 & 166 & 606 & 39 \\
\hline $1 / 4$ & ses & 158 & 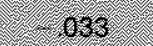 & (t) \\
\hline
\end{tabular}

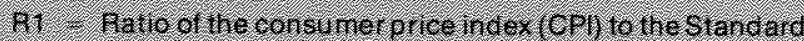

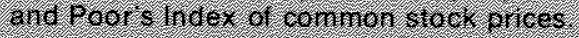

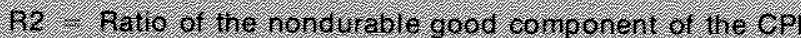

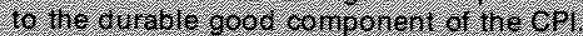

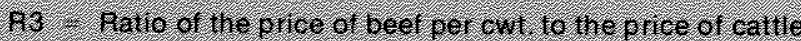
ilet thear.

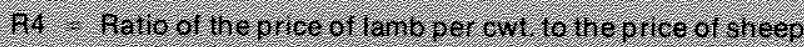
piet litate

Catcelated rom aninil dats.

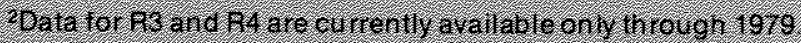

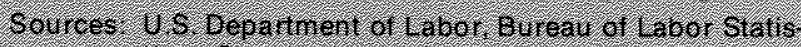
tics. Standard and poors. Us pepatiment or

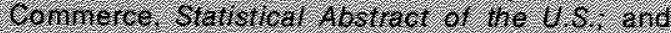

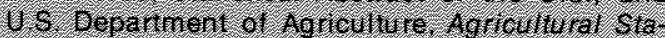

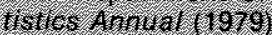

we are unable to detemine whether the change in the average level of the ratio of the nondurable to the durable goods component of the CPI is significant. ${ }^{13}$ Thus, these ratios provide no statistical evidence that the real rate of interest has changed, on average, between the two time periods. Therefore, the increase in the average level of nominal interest rates in recent years cannot be attributed to an increase in the average level of the real interest rate.

Nominal interest rates were more volatile during the $1967-81$ period than during the $1954-66$ period as shown by the statistically significant increase in their variances in the more recent period (see table 2). ${ }^{14}$ This increase in volatility however, can not be

13When employing the test for differences in means for smallsized samples (less than 30 observations), the samples are assumed to be drawn from nommaly distributed populations having the same standard deviations. This assumption is violated in the case of $\mathbf{n} 2$ (see the $\mathrm{F}$-statistic in table 4) and, thers, the t-test for the significance of the difference in means is inappropriate.

${ }^{14}$ The $F$ test is the ratio of the larger variance to the smaller variance, where the variance is the squate of the standard deviation. For the sample sizes used, an F-ratio in excess of 1.60 is safficient to reject the (null) hypothesis that the variances are equal with 95 percent confidence.

\section{Table 4}

Standard Deviations of Proxies for Changes in the Real Interest Rate

\begin{tabular}{|c|c|c|c|}
\hline & 195466 & $196 / 160$ & If staluster \\
\hline 11 & 450 & 40. & 1024 \\
\hline 12 & 8.625 & 058 & 5.574 \\
\hline 7) & 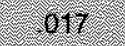 & 628 & 1.60 \\
\hline$\sqrt{4}$ & 04 & -105 & 1.6 \\
\hline \multirow{2}{*}{\multicolumn{4}{|c|}{ 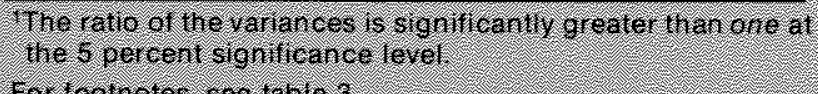 }} \\
\hline & & & \\
\hline
\end{tabular}

explained by increased volatility in the real rate of interest. As shown in table 4, only one relative price ratio, the ratio of the nondurable to the durable goods component of the CPI, demonstrates any significant increase in variance. For three price ratios, there is no statistically discemible change in their variances between the two periods. Again, the preponderance of evidence suggests that the increased volatility in nominal interest rates did not arise from greater variation in the real rate of interest. Therefore, the solution to the puzzle of nominal interest rate behavior in the more recent period lies elsewhere.

\section{Expected Inflation, Actual Inflation and Measured Inflation}

The economic theory summarized by equation 1 suggests that if changes in the real rate of interest do not explain the increases in the mean level and volatility of nominal interest rates between the two periods, then changes in the expected rate of inflation must be responsible. To analyze properly the impact of inflation on nominal interest rates, however, three different concepts regarding the rate of inflation must be distinguished: I) the expected rate of inflation in the general level of prices, 2) the actual or true rate of inflation in the general level of prices and 3) the measured rate of inflation.

It is the expected rate of inflation $\left(\pi^{*}\right)$ that is important in explaining the behavior of nominal interest rates; this is the inflation variable that appears in equation 1 . Unfortunately, the expected inflation rate is not directly observable.

The expected inflation rate represents the public's 
best "guess" about what the actual or true future rate of inflation in the general level of prices will be. This guess generally will be incorrect for any specific time period; the future is, after all, uncertain and, therefore, subject to a variety of random shocks. However, economic theory suggests that because there are large wealth consequences associated with these predictions, estimates of the true rate of inflation made by individuals will be unbiased; that is, although these predictions generally will be wrong due to the occurrence of unexpected future events, they will not consistently over- or underpredict the true rate of inflation. ${ }^{15}$ As a result, if we knew about changes in the true rate of inflation, we could use this infomation as a proxy for changes in the (unobservable) expected rate of inflation.

However, the true rate of inflation in the general price level is also unobservable. We have no direct information on this rate; instead, we have information on several different measured rates of inflation. These are typically derived from changes in various price indices, such as the CPI, the GNP deffator and the Index of Producer's Prices.

Unfortunately, the measured rate of inflation may, under certain circumstances, differ significantly from the true rate of inflation in the general level of prices. This potential divergence occurs because the price indices mentioned above typically include a relatively narrow sample of all of the goods that are available for purchase. In particular, they generally exclude the prices of existing capital assets, thereby placing greater weight on the prices of current

\footnotetext{
${ }_{15 * *}$ Betore proceeding to specific statistics, it is important to emplasize the broad fact that ... business foresight exists and that the accuracy and power of this foresight is greater today than ever before... Every chance for gaix is eagerly watehed. An active and intelligent speculation is constantly going on, which ... performs a well-known and provident function for society. Is it reasonable to believe that foresight ... has an exception as applied to falling or rising prices? $\mathrm{O}_{\mathrm{F}}$ if so, can the academic... assume himself possessed of a foresight of which he says the practical man is incapable? It is the practical man's business to fonesee. It is he who first gathers the facts and statistics. . . It is he who watehes the trends... And it is in his trade joumals that we find the frat discussions of the probable effect of gold discoveries or silver legishation on prices and trade. The theorist can afd in these predictions only by supplying the principle on which they are con structed." Irving Fisher, Ampreciation and Interest (Augustus M. Kelley, 1965), pp. 36-37. For further discussion of efficient markets, see Eugene F. Fana, "Efficient Capital Markets: A Review of Theoretical and Empirical Work," Joumal of Finance, Papers and Proceedings (May 1970), pp. 383417.

"Armen A. Alchian and Benjamin Klein, "On a Correct Measure of Intation," Joumal of Money, Credit and Banking Februay 1973), pp. 173-91
}

consumption goods. ${ }^{16}$ Measured rates of inflation will therefore produce biased estimates of the true rate of inflation in the general level of prices on those occasions when the prices of present consumption goods are changing relative to the prices of capital assets. This specific bias occurs whenever the real rate of interest changes. Consequently, the measured inflation rate overstates the true rise in the general level of prices when the real rate of interest rises, and understates the true rate of inflation when the real rate of interest declines.

Fortunately, it is possible to "link" the unobservable average rate of expected inflation to the observable average rate of measured inflation, if expectations of individuals regarding the future rate of inflation yield unbiased predictions of the true rate of inflation and if, in addition, the average level of the real interest rate is unchanged over the period of analys is. The first "if" enables us to link the expected to the actual rate of inflation. The second "if" lets us relate the actual to the measured rate of inflation.

Note the critical importance of our previous finding that the average level of the real interest rate did not change between the 1954-66 period and the $1967-80$ period. Because of this, we would not expect the average measured rate of inflation over these two periods to differ from the true rate of inflation. ${ }^{17}$ Because we believe that the expected rate of inflation is an unbiased estimate of the actual rate of inflation, we can directly link the average rate of expected inflation to the average rate of measured inflation.

\section{The Relationship Between Measured Inflation and Nominal Interest Rates}

Inflation statistics using the GNP implicit price deflator are reported in tables 1 and 5 . The data in table 1 indicate that, on average, the measured rate of inflation ( $\pi$ ) was 4.24 percent higher during the $1967-81$ period than during the $1954-66$ period. This increase closely parallels the 384 to 420 basis-point increases in the average levels of the nominal interest rates reported in table 1 . In fact, none of these

\footnotetext{
17While it is true that yeartonear changes in the real tate of interest have occurred and thus have introdaced a bias into the measured rate of inflation at those points in time, the se flucturtions have apparently averaged out. As a result, apart from other problems, any observed difference between the aterage measured rate of inflation between the two subperiods can not be explained by meastrement error introduced by a change an the anerage level of the real rate of interest.
} 
increases in the aterage levels of interest rates are significantly different from the increase in the aterage level of inflation. ${ }^{18}$ The rise in the average rate of inflation fully "explains" the average increases in these nominal interest rates.

Data for various measures of variability in the measured rate of inflation for the two periods are reported in table 5 . Two of the three measures indicate increased variability in the rate of inflation. The standard deviation of the measured rate of inflation in the more recent period is almost twice that in the earlier period; this closely parallels the increase in the standard deviations of the nominal interest rates reported in table 2. The standard error associated with regressing the rate of inflation on a simple time trend has increased by 43 percent. Only the mean quarter-to-quarter absolute change in the rate of inflation shows no increase in the later period.

This evidence suggests that the rise in the average level of nominal interest rates since 1967 and, to a lesser extent, their increased volatility can be explained by the increase in the level and volatility of the rate of inflation. What remains, therefore, to complete the analysis of interest rate movements in recent years is to determine why the rate of inflation has changed.

\section{Determinants of the Rate of Inflation}

The increase in the average level and volatility of the rate of inflation during the 1967-81 period could have been produced by changes in the behavior of the growth in the money stock $(\dot{M})$, in the growth of its velocity of circulation $(\dot{V})$, or in the growth of real output $(\dot{Y})$. The relationship between the rate of inflation and these variables is given by the following identity:

$$
\text { (2) } \pi=\dot{M}+\dot{V}-\dot{Y} \text {. }
$$

The rate of inflation is positively related to changes in the growth rates of the money stock and its velocity of circulation, and inversely related to changes in the growth rate of output.

Economic theory converts this identity into a hypothesis about the long-term relationship between the growth rate in money and the rate of inflation by

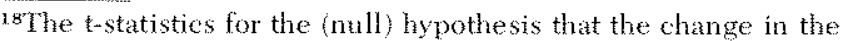
interest rates between the two periods is exactly 4.24 percent are $-0.16,-1.49,-0.20$, and -0.89 , for the interest rates shown in table 1 , respectively.
}

\section{Table 5}

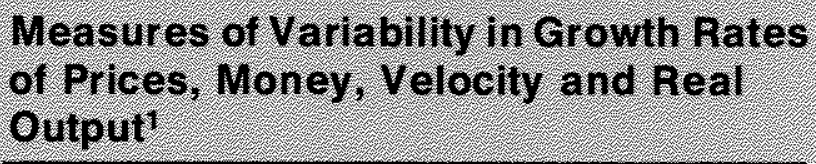

\begin{tabular}{|c|c|c|c|}
\hline & 196466 & 19178 & \\
\hline \multicolumn{3}{|c|}{ standaro devituons } & frstatist \\
\hline ris & 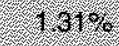 & $2.42 \%$ & 3.42 \\
\hline $\mathrm{n} / \mathrm{B}$ & 2.32 & 276 & 141 \\
\hline (2) & 2.85 & 678 & 103 \\
\hline r. & 420 & 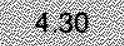 & 105 \\
\hline 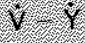 & 862 & 868 & 167 \\
\hline
\end{tabular}

\begin{tabular}{|c|c|c|}
\hline th & 1748 & $1,68 \%$ \\
\hline Mise & 463 & 249 \\
\hline 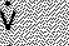 & 8.45 & 419 \\
\hline t) & (1) 49 & 4,7 \\
\hline 1) & 205 & 280 \\
\hline
\end{tabular}

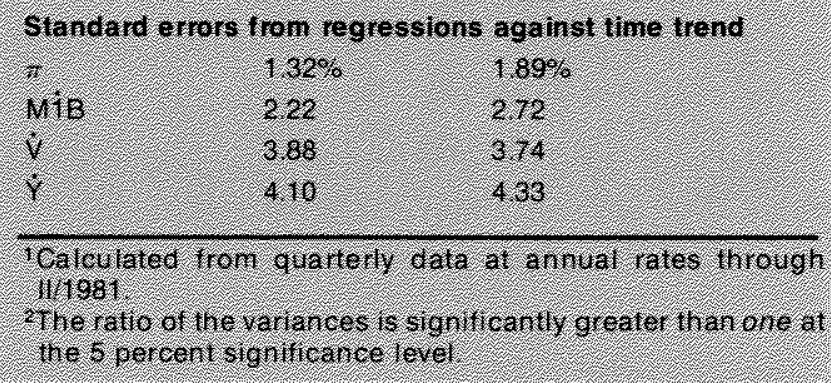

arguing that the long-term growth rates in velocity and output are essentially unaffected by changes in the long-term growth rate in the stock of money. ${ }^{19}$ As a result, changes in the long-term rate of growth in the money stock will be directly matched by changes in the rate of inflation if the long-term rates of growth in velocity and output remain unchanged.

Since our analysis covers two relatively long time periods, we should be able to determine the extent to which each of these factors has influenced the long-term changes in the rate of inflation and, by extension, the changes in nominal interest rates.

\footnotetext{
${ }^{19}$ Tring Fisher, The Purchasing Power of Money (Augustus $\mathrm{M}$ Kelley, 1963), p. 14, notes that: "This theory, though often cnidely fomalated, has been accepted by Locke, Hume, Adam Smith, Ficardo, Mill, Walker, Marshal, Hadley, Fetter, Kemmerer, and nost writers on the subject. The Roman Jul urs Paulus, about 200 A.D., states his belief that the value of noney depends upon its quantity." See also pp. I57-59. On pige 296-97, Fisher states that the "Law [emphatsis in original] of direct proportion between [the] quantity of money and the price level . . is as important to the theory of money as Boyle's Law is to the physical theory of gases."
} 


\section{Has the Long-Term Growth Rate in Real Output Changed?}

The long-term growth rate in output is primarily determined by the rate at which capital is accumulated. ${ }^{20}$ The average grow th rate in real output was 3.4 percent per year over the $1954-81$ period. Of course, the growth rate of output fluctuates considerably from quarter to quarter around its long-term a verage rate. The pattern of the short-term variations in output growth and the average rate of growth over the entire 1954-81 period are shown in the first tier of chart 2 .

The quarter-to-quarter growth rates in real output vary considerably, from a positive 11 percent during the first quarter of 1973 to a negative 10 percent during the second quarter of 1980 . However, as the summary statistics in tables 1 and 5 indicate, both the average rate of grow th in output and its variance are essentially unchanged between the two periods. The reported differences in both the mean growth rates and variances are not statistically significant. Thus, the statistical evidence does not support the claim that changes in the average growth in real output and its variability are responsible for the higher and more variable inflation rate.

\section{Has the Long-Term Growth Rate in Velocity Changed?}

The velocity of money measures the relationship between total spending and the stock of money. The larger the velocity, the greater the amount of spend. ing that a unit of money will finance during any given period. ${ }^{21}$ This is why, given the quantity of money and real output, an increase in velocity is associated with a rise in prices.

Like real output, velocity has been increasing. The average rate of growth in velocity was about 3.3 percent per year over the $1954-81$ period, virtually cancelling out the effect on prices resulting from the average growth in real output as shown in equation 2.

\footnotetext{
20For a complete discussion, see Fisher, The Purdasing power of Money, pp. 74-111. Fisher includes the quantity of natural reson res, the division of labor, techniçue of production, variety of wants, facitities for tran spontation, institutional arrangements regarding the rights of individuals to contrat, etc.

${ }^{2}$ Velocity depends upon such things as the expected rate of inflition, the rate at which checks atre cleared and the use of credit. In add ition to these, Fisher, The Purchasing Poucer of Money, p. $79-89$, adas preferences to hoard, the timng and regulurity of receipts and disbursements, population density and transportation facilities.
}

The second tier of chart 2 shows quarter-to-quarter grow th rates in velocity and the average grow th rate for the entire $1954-81$ period. These quarter-toquarter growth rates fuctuate considerably around the long-term average. However, as the data in tables 1 and 5 indicate, there has been no significant change in the average rate of growth in velocity or in its volatility between the two periods. Differences in the mean growth rates and the variances between the two periods are not statistically significant. Consequently, the increase in the average level and variability of the rate of inflation can not be explained by changes in the growth rate of velocity.

\section{Has the Relationship Between Velocity and Real Output Growth Changed?}

Although the increase in the level and volatility of inflation since 1967 is not explained by changes in the growth rates of velocity and real output when analyzed separately, it is really the difference between these two growth rates that measures the longer-run, non-monetary influence on inflation (see equation 2). Therefore, an explicit analysis of this difference may reveal significant changes that do not appear when velocity and real output growth rates are examined individually. Evidence bearing on this issue is presented in tables 1 and 5 ; the difference is depicted graphically in the third tier of chart 2 .

As shown in table 1, there has been no statistically significant increase in the average difference between the growth rates for velocity and real output. Not only is this difference not significantly different from zero in each period shown, the 0.16 rise in the difference in the later period is explainable by sampling error alone. ${ }^{22}$ Thus, the increase in the average inflation rate since 1967 can not be attributed to significant changes in the growth of velocity and real output, whether taken separately or in tandem.

The results in table 5 suggest, however, that the increased volatility of inflation since 1967 has been accompanied by a significant increase in the volatility of the difference between velocity growth and real output growth. The rise in the standard deviation is statistically significant; the mean absolute quarter-to-quarter changes have risen 37 percent in the $1967-81$ period. Therefore, the greater volatility in this difference since 1967 has contributed to increased variability in the rate of inflation.

\footnotetext{
${ }^{22}$ The t-statisties for the difference between velocity and ontput growth in each period are -0.74 for 1954.66 and -0.23 for $1967-81$
} 


\section{Chart 2 \\ Growth Rates of Real Output and Velocity}

Percen

Short-run real output growth and average real output growth

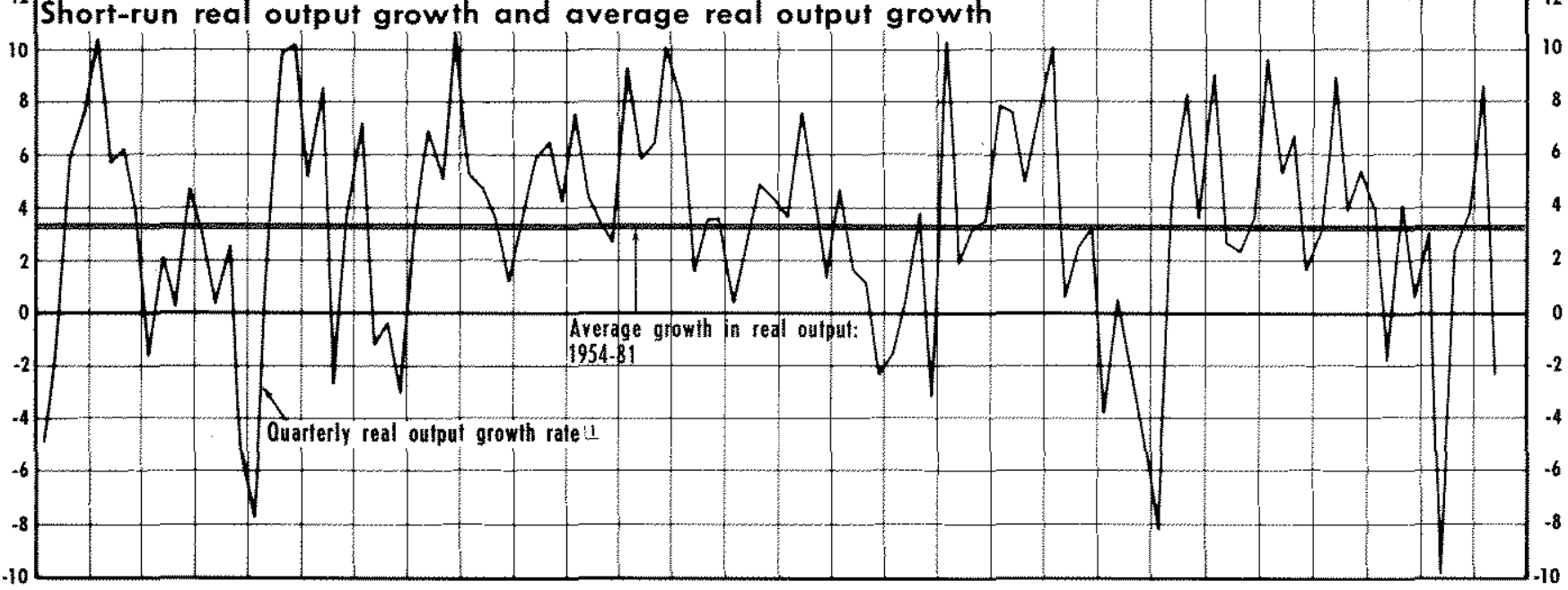

Percent

14 Short-run velocity growth and average velocity growth

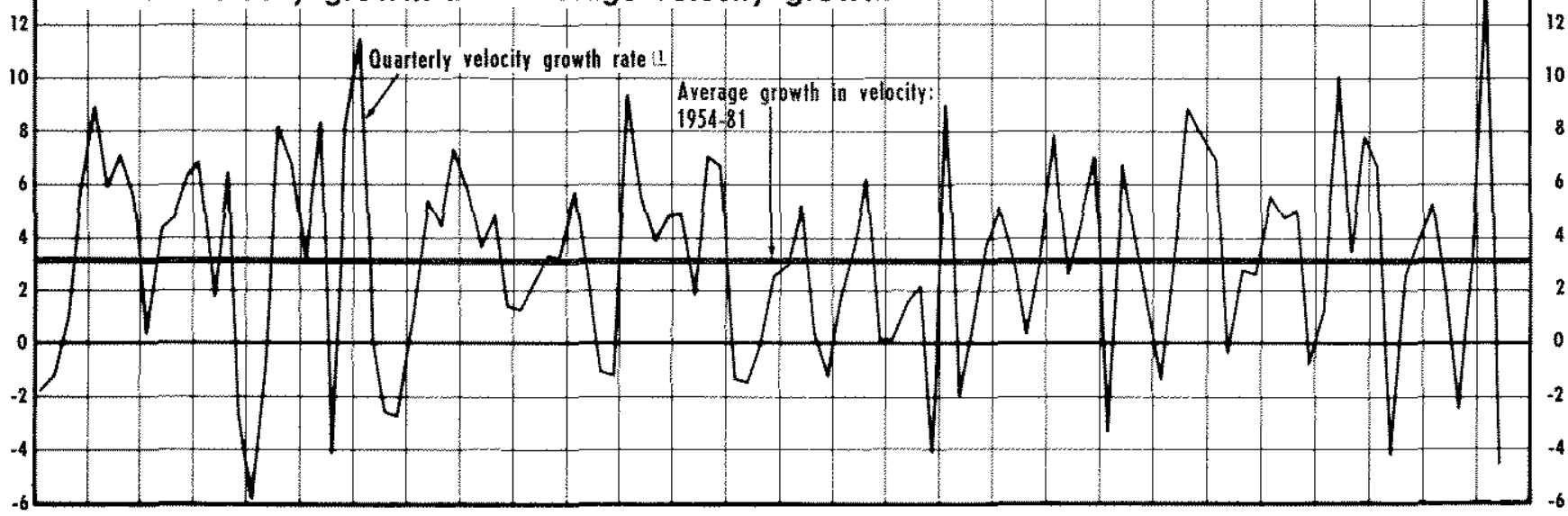

Percen

Percea

12 Difference between velocity growth rate and real output growth rate

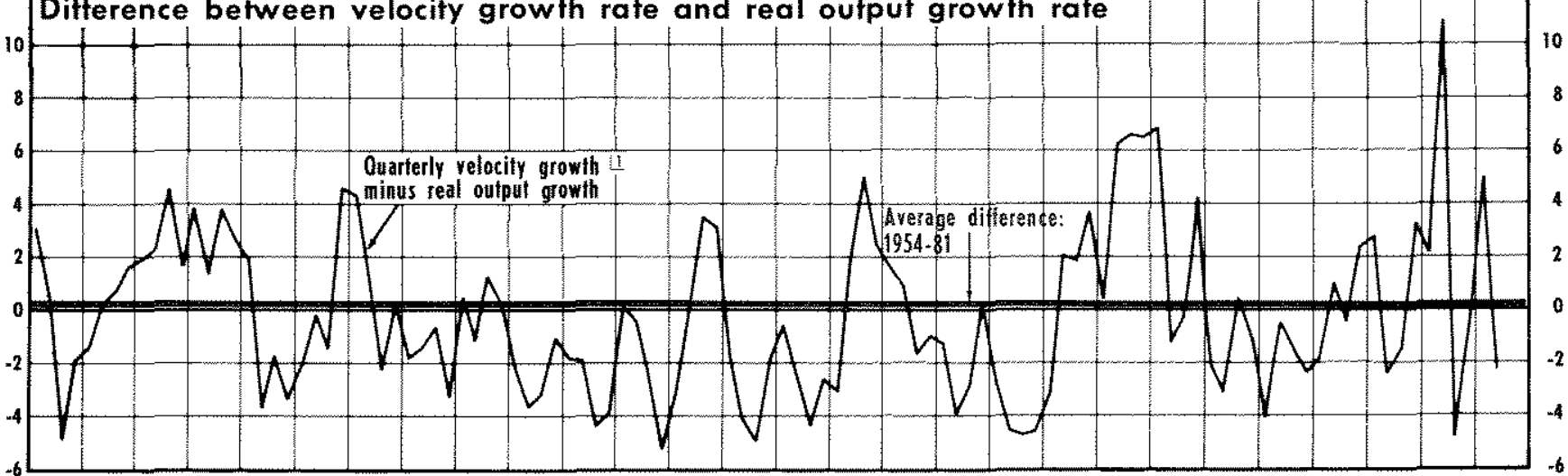

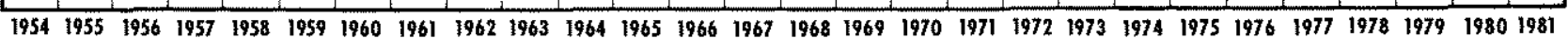
1 Compounded annual rates of change-

Lotest data plotiad: 2nd autartor 


\section{Growth Rates of GNP Implicit Price Deflator and MIB}
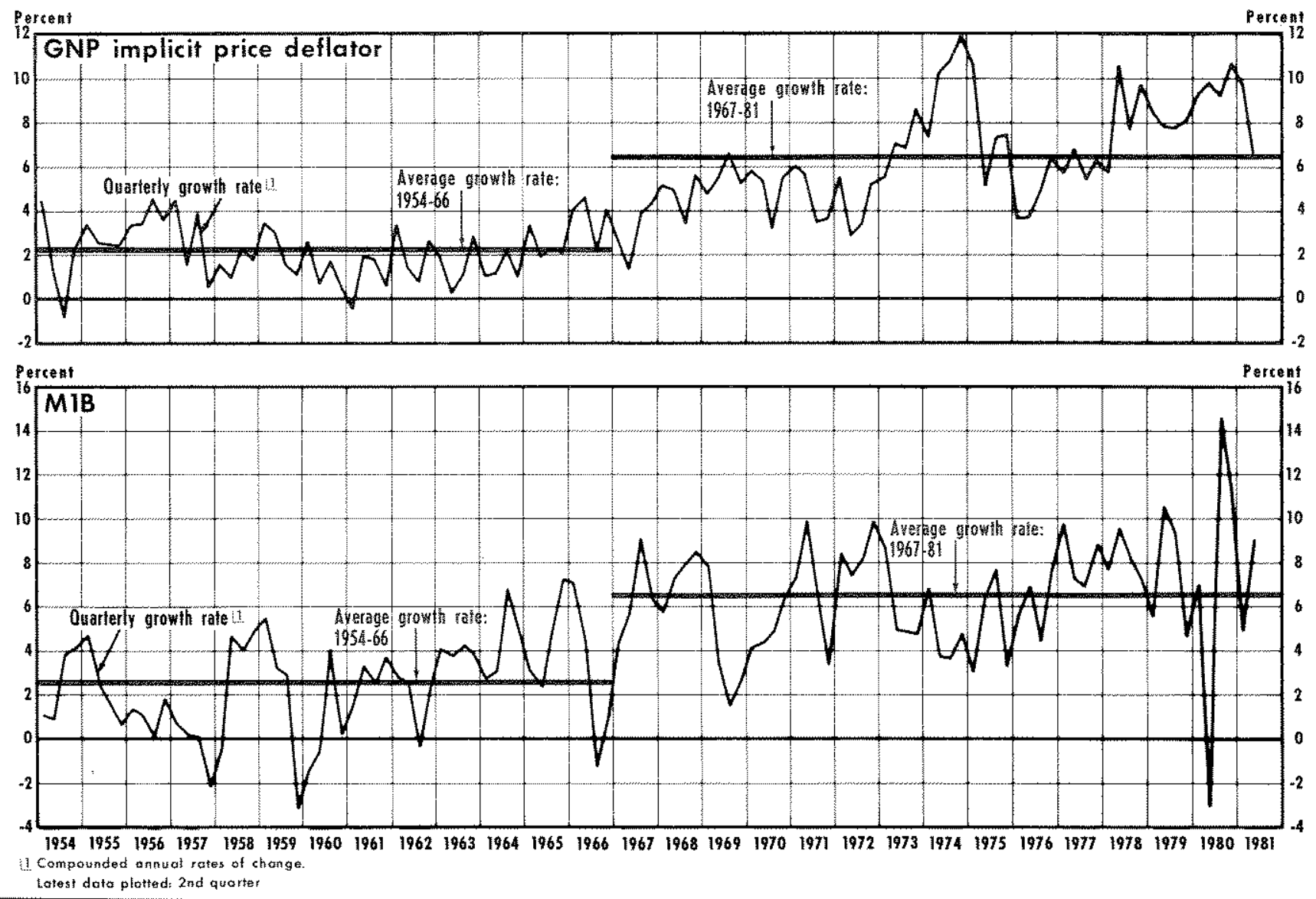

\section{Money Growth and Inflation}

As we observed above, the combined effect on the rate of inflation of the average growth rates in velocity and real output have been virtually offsetting - their net impact on the rate of inflation was essentially zero, as shown in the third tier of chart 2 . Therefore, the rate of inflation since 1954 must be closely related to the rate of growth in the money stock. The close long-run relationship between the growth in M1B and the rise in the GNP implicit price deflator in both periods is evident from a comparison of their mean growth rates in table $1 .{ }^{23}$ During

${ }^{23}$ For evidence that $M 1 B$ is the preferable monetary aggregate to use ha assessing the noney-price link, see Keith M. Carlson, "The Lage From Money to Prices," this Review (October 1980) Da. 3-10; Keth M. Carlson and Scott F. Hein, "Monetary Aggregates as Monetary Indicators," this Retiew (November 1980 , pp. 12-21, R. W. Hafer, "Selecting a Monetary nid fator: A Test of the New Monetary Aggregates" this Review (February 1981), pp. 12-18; and h. W. Hafer, "Much Ado Abont M2," this Review (October 1981), pp, 13-18. the 1954-66 period, M1B growth averaged 2.46 percent per year and prices rose, on average, 2.19 percent per year, since 1967 , grow th in MIB has averaged 6.52 percent per year and prices have risen, on average, at an annual rate of 6.43 percent. There is no significant statistical difference between the long-run growth in $M 1 B$ and that in prices in either period. The small differences that we observe between inflation and money growth in both periods can be attributed simply to random error. ${ }^{24}$

The close relationship between inflation and money growth is important because, unlike the other variables cited above, the long-term rate of growth in the stock of money is a direct consequence of monetary policy actions. Although the money stock may vary randomly over periods up to a month or

$2 \times$ The $t$-statistics for the hypothesis that the rate of inflation equals the rate of money growth are -0.73 for $1954-66$ and -0.19 for $1967-81$. 
two, these short-run fluctuations have virtually no discemible impact on inflation. As the data in table 1 point out, the crucial variable for explaining the long-rum behavior of prices is the behavior of the policy-determined, long-term rate of growth in money.

The significant rise in the average rate of growth in the money stock (MiB) and its volatility are shown in tables 1 and 5 . The substantial increase in the long-term average growth rate in money between the two periods essentially accounts for the entire change in the rate of inflation. The average annual growth rate in $\mathrm{M} 1 \mathrm{~B}$ increased by 4.06 percent between the two periods; the average rate of inflation rose 4.24 percent per year. There is no sign ificant statistical difference between the average increase in the rate of inflation and the rise in $M I B$ growth since 1967.25

Also, as shown in table 5 , money growth has become more volatile since 1967 . Its standard deviation has increased by 19 percent over the more recent period. Further, its mean absolute quarter-toquarter change has risen 53 percent; its standard error (from a time-trend regression) has increased 23 percent.

Chart 3 provides evidence of the close relationship between the average rise in the growth of prices and

25The t-statistic for the (nell) hypothesis that the rise in the rate of inflation since 1967 actually equals 4.06 percent the aise in money growth is 0.49 . money and their increased variability. These results indicate that the increase in the average rate of inflation and, to a great extent, the rise in its volatility can be directly associated with similar movements in the growth of $\mathrm{M} 1 \mathrm{~B}$.

\section{Conclusion}

Over the past 15 years, nominal interest rates have been higher and more volatile, on average, than they were from 1954 to 1966. Judging from the volume of public discussion, these increases are economically and politically disquieting. Besides satisfying a natural curiosity about why such drastic changes in financial markets have occurred, one major reason for studying the factors responsible is to determine the extent to which policy actions can influence interest rate movements.

The evidence in this article suggests that higher and more variable money growth since 1967 have been primarily responsible for the longer-term rise and increased variability in interest rates. Alternative explanations of the movements in interest rates - that they are due, in part, to higher and more variable real interest rates or to significant changes in the behavior of velocity or real output growth are not generally supported by the longer-run evidence cited here A corollary to the andysis is that, barring fortuitous (but so far unobserved) changes in velocity and output growth, only an extended period of lower and less variable money growth is likely to generate lower and more stable interest rates.

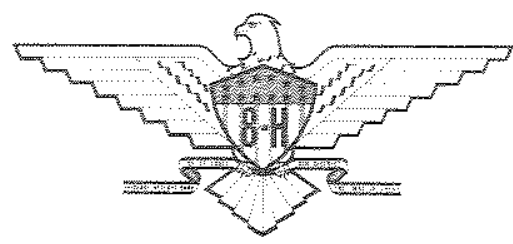

